Historic, Archive Document

Do not assume content reflects current scientific knowledge, policies, or practices. 

1.49.9

576.324

$$
\text { c.. } 2
$$

United States

(14) Department of

Agriculture

\section{Management of Lodgepole Pine in Even-Aged Stands in the Central \\ Rocky Mountains}

Fort Collins,

Colorado 80526

Robert R. Alexander

Research Paper

Carleton B. Edminster

RM-229

(1)

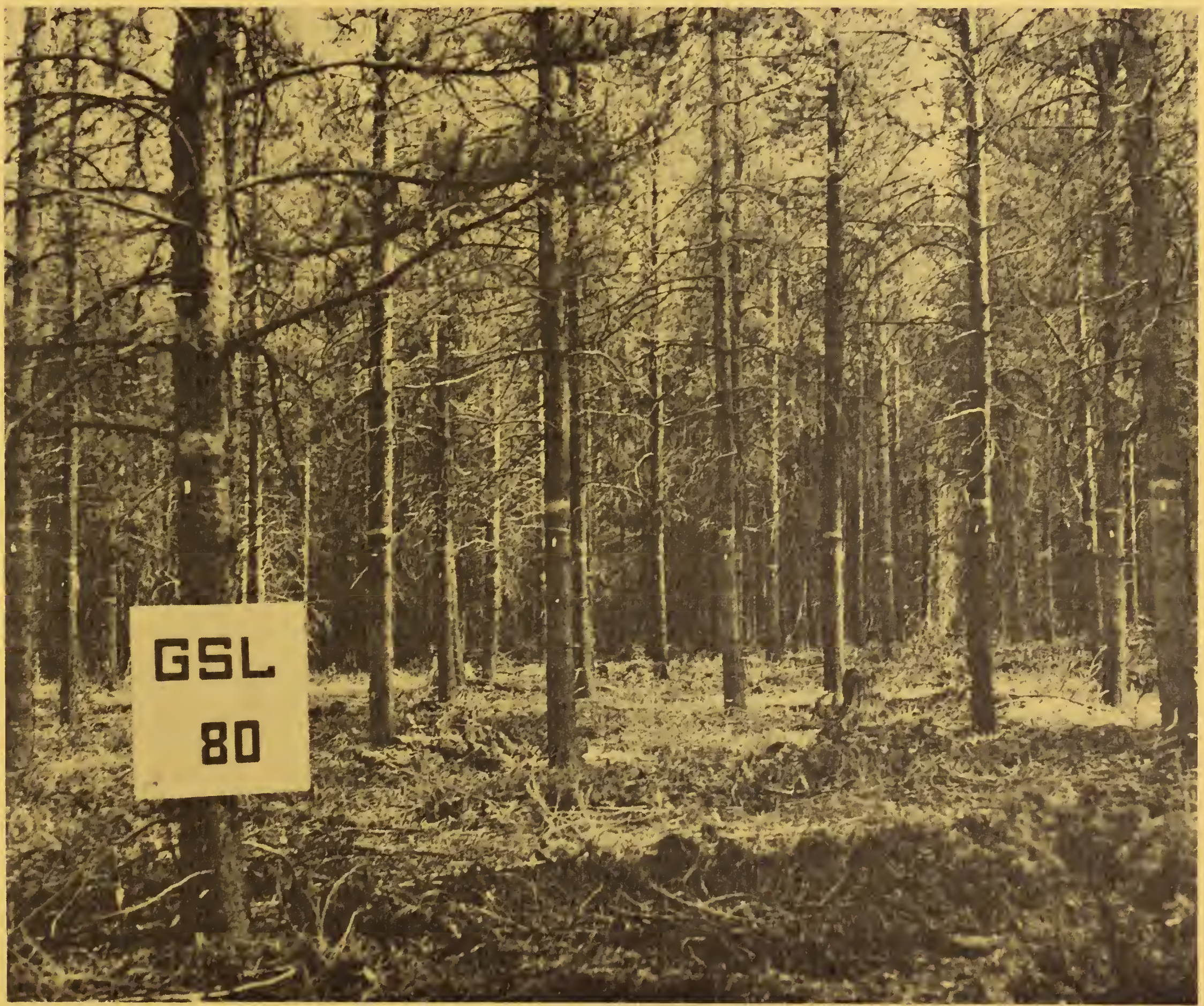




\title{
Foreword
}

This publication is intended to supplement the authors' article "Lodgepole pine management in the central Rocky Mountains," Journal of Forestry 78(4):196-201. Included are graphical, tabular, and descriptive information that could not be included in the Journal of Forestry, but are useful to land managers.

-Robert R. Alexander

\begin{abstract}
Potential production of lodgepole pine in the central Rocky Mountains is simulated for various combinations of stand density, site quality, ages, and thinning schedules. Such estimates are needed to project future development of stands managed in different ways for various uses.
\end{abstract}




\section{Management of Lodgepole Pine in Even-Aged Stands in the Central Rocky Mountains}

Robert R. Alexander, Chief Silviculturist

and

Carleton B. Edminster, Mensurationist

Rocky Mountain Forest and Range Experiment Station' 


\section{Contents}

Silviculture of Lodgepole Pine in the

Page

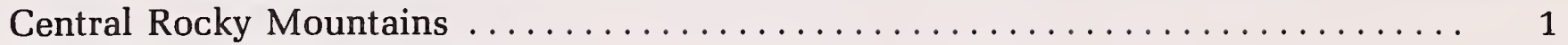

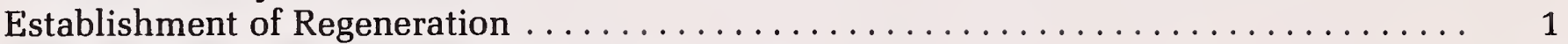

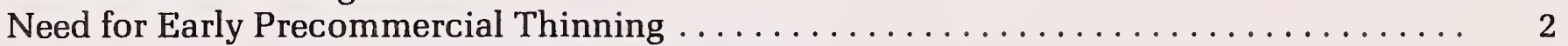

Estimates of Growth Under Intensive Management . . . . . . . . . . . . . . . . . . . . 2

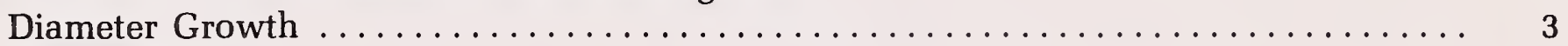

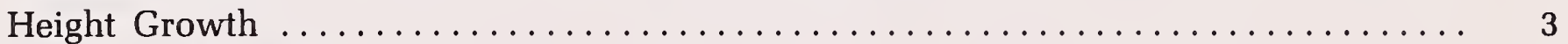

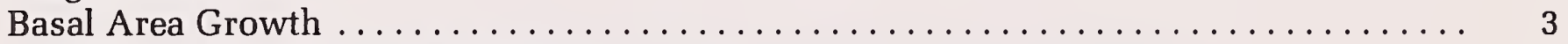

Total Cubic-Foot Volume Increment $\ldots \ldots \ldots \ldots \ldots \ldots \ldots \ldots \ldots \ldots \ldots \ldots \ldots \ldots \ldots$

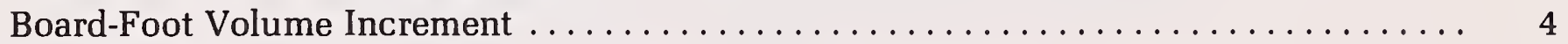

Maximizing Board-Foot Volume Yields $\ldots \ldots \ldots \ldots \ldots \ldots \ldots \ldots \ldots \ldots \ldots \ldots$

Tradeoffs to Increase Values of Other Resources $\ldots \ldots \ldots \ldots \ldots \ldots \ldots \ldots \ldots \ldots \ldots \ldots$

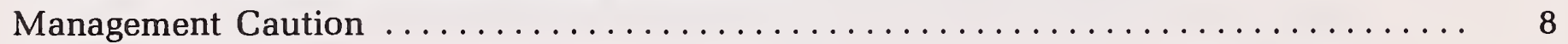

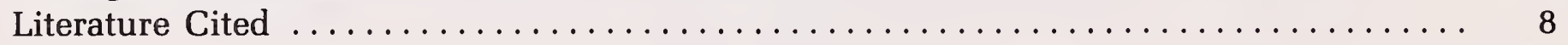




\title{
Management of Lodgepole Pine in Even-Aged Stands in the Central Rocky Mountains
}

\author{
Robert R. Alexander and Carleton B. Edminster
}

\author{
Silviculture of Lodgepole Pine \\ in the Central Rocky Mountains
}

Lodgepole pine (Pinus contorta Dougl. ex Loud) is the second largest timber resource in the central Rocky Mountains in volume and area of commercial forest (Choate 1963, Miller and Choate 1964). It reaches maximum development in the subalpine forest zone, on south and west slopes, at elevations between 8,500 and 10,500 feet.

Lodgepole pine forests have yielded a wide variety of timber products and forage for livestock and big game, but other resources are now becoming increasingly important. How these forests are handled affects all uses. For example, if timber volume is the primary objective, growing stock level ${ }^{2}$ (GSL) should be maintained at 120 to 160 . Forage production and water yield are substantially increased only at much lower GSL's. Low to medium GSL's generally are considered necessary to improve recreational opportunities and enhance esthetics. Wildlife habitat varies from uncut to open forests. Improvement of middleground and background esthetics generally requires a combination of open, low stocking, and high stocking levels that provide contrasts.

Although land managers must increasingly direct their practices toward multiple use, these practices must be based on sound silvicultural principles. Moreover, land managers must understand the tradeoffs between the timber resource and other physical, social, and economic considerations.

Clearcutting old-growth stands and allowing cutover areas to regenerate naturally, regardless of the time required or the stocking achieved, was a common practice for many years. Today, increased management intensity requires (1) prompt replacement of the old stand with a new stand, (2) increasing growth of the new stand by control of stand density, and (3) increasing yields by

\footnotetext{
${ }^{2}$ Growing stock level (GSL) is defined as the residual square feet of basal area when average stand diameter is 10 inches d.b.h. or more. Basal area retained in a stand with an average diameter of less than 10 inches is less than the designated level (Myers 1971, Edminster 1978). Tables A-1, A-2, and A-3 in the appendix give the basal area, number of trees, and square spacing in stand with average diameters after thinning of 2 to 10 inches, for GSL levels 40 to 160 .
}

periodic thinning to maintain stocking control and growth rates.

In old-growth, unmanaged stands, average annual growth is only about 25 to $40 \mathrm{fbm}$ per acre, mainly because of the large number of small trees and the high incidence of dwarf mistletoe (Arceuthobium americanum Nutt. ex Engel.). Under even-aged management, annual net growth can be increased to 150 to $400 \mathrm{fbm}$ per acre by controlling stand density and reducing dwarf mistletoe infection (Edminster 1978).

Stand density control offers the greatest opportunity for increasing wood production by increasing growth rates and reducing mortality, but harvested stands must be replaced promptly to minimize the time required to reach maximum yields. Low stumpage values have also hindered intensive management in the central Rocky Mountains. Improving stumpage values will allow the forest manager to do the cultural work needed to increase timber production.

\section{Establishment of Regeneration}

Lodgepole pine is best maintained as a vigorous, productive forest under an even-aged management system. While clearcutting is the most common method of converting old growth to managed stands, the standard shelterwood system also can be used where wind and pest problems permit, or where regeneration requirements or management objectives are best met by maintaining continuous cover. Uneven-aged systems generally are not effective in ensuring natural regeneration or increasing growth of the replacement stand.

Entire stands, blocks, patches, or strips can be clearcut or shelterwood cut. Clearcutting can be readily adapted to multiple-use land management by judicious selection of size, shape, and arrangement of openings, in combinations with other high-forest cutting practices. With a clearcut option, the size of opening that is likely to receive sufficient seed to restock receptive seedbeds is influenced by whether the seed is dispersed by open or closed cones. It can not be assumed that the cone habit is either serotinous or nonserotinous. Each stand must be examined and classified as closed cone, open cone, or intermediate. If the stand is 
classified as closed cone, it then must be determined if sufficient sound seed is stored in closed cones to provide an adequate seed source for natural regeneration.

Clearcutting stands with serotinous cone habit.-Clearcuts of various sizes and shapes will restock if there is enough seed. However, there is only one opportunity for natural regeneration, because the seed supply is in the slash-borne cones. There is no advantage to cutting openings larger than 30 to 40 acres, even for dwarf mistletoe control, and openings of 10 to 20 acres would be more compatible with other uses. On south slopes and other difficult regeneration chances, it may be desirable to cut openings smaller than 10 acres to provide a supplemental seed source in trees standing around the perimeter.

Clearcutting stands with nonserotinous or intermediate cone habit.-The cutting unit must be designed so that seed from the surrounding timber margin reaches all parts of the opening, unless artificial regeneration is planned. Effective seed dispersal distance from standing lodgepole pine has not been studied in the central Rocky Mountains, but studies elsewhere (Boe 1956, Dahms 1963, Tackle 1964) indicate that, with favorable seedbed and environmental conditions, the effective seeding distance in lodgepole pine is about 150 feet. The maximum width of opening likely to restock to natural reproduction is, therefore, 300 feet, or about four to five times tree height. Further, it is not likely only one seed crop will provide enough seedfall for adequate stocking. On south slopes, openings should be smaller-150 feet wide, or about two to three times tree height. If larger openings are cut, the area beyond effective seeding distance must be planted.

If a shelterwood option is used, seed for regeneration is dispersed from trees left standing on the area after the seed cut (nonserotinous cones), or dispersed from cones attached to logging slash or knocked loose on the ground (serotinous cones) after the seed cut. Logging damage to established regeneration must be controlled by (1) locating and marking skid roads on the ground at about 200-foot intervals, and confining skidding equipment to these skid roads to reduce indiscriminate travel over the cutover area; (2) felling trees in a herringbone pattern to the skid road to reduce disturbance when logs are moved onto the skid road; and (3) close coordination between felling and skidding operations, especially in stands with large volumes, where it is necessary to fell and skid one tree before another is felled (Alexander 1974).

Regeneration may be slow to establish and seedlings poorly distributed, regardless of cutting method or cone habit, if seed supply is inadequate (viable seed in closed cones is often destroyed during slash treatment), seedbeds unfavorable, or environmental conditions adverse after seed dispersion. If cutover stands are not adequately stocked within 5 years after the final harvest, the manager must take action under the regulations of the National Forest Management Act of 1976 to artificially regenerate the areas.

With any of the even-aged systems, the minimum initial stocking recommended is 1,200 to 1,500 stems per acre at age 10 years (Alexander 1974). This density ensures that at least 1,000 stems per acre will survive to age 30 years, without reduction in height or diameter growth (Alexander 1960).

\section{Need for Early Precommercial Thinning}

Establishing a new stand is only the beginning. Trees must have room to grow to reach merchantable size in a reasonable time. Where lodgepole pine has regenerated after clearcutting, stands are often overstocked. For example, with 4,000 to 5,000 stems per acre, the trees will reach an average diameter of about 2 inches d.b.h. in 30 years, and one-fourth of the 120-year rotation will have been passed (Alexander 1965). For acceptable growth rates, stands must be thinned to 1,200 to 1,500 stems per acre during the first 10 years.

Although enough well-distributed seedlings have been established within 5 years using the shelterwood system, growth is retarded if the overwood is not promptly removed. In stands infested with dwarf mistletoe, the longer the overwood remains in place, the greater the probability of transmitting the disease to the new stand (Alexander 1975).

\section{Estimates of Growth Under Intensive Management}

Intensive management provides many opportunities for increasing usable wood production, but estimates of stand development under various management regimes are needed.

The best information on lodgepole pine growth from sapling stage to final harvest, under even-aged management, with either a clearcut or shelterwood cut, is provided by field and computer simulation procedures developed by Myers (1971) and Myers et al. (1971) and refined by Edminster (1978). The procedures were developed from field data on past growth related to stand density, age, and site quality. Data were obtained from a large number of permanent and temporary plots in thinned stands throughout the central Rocky Mountains.

The modeling concept used in these programs regards the whole stand as the primary model unit, characterized by average values. The equations upon which the growth and yield simulations are based are given in the program listing in the appendix of Myers et al. (1971). The programs project stand development by consecutive, 10-year periods, and include relationships to project average stand diameter, average dominant and codominant height, and number of trees per acre for stands not infested by dwarf mistletoe. Separate relationships express effects of dwarf mistletoe and changes in the intensity of infestation. Average diameter at the end of a projection period is a function of average diameter at the beginning of the period, site index, and basal area per acre. Periodic average dominant and codominant height growth at managed stand densities is a function of age and site index. Periodic mortality is a function of average diameter and basal 
area per acre. Stand volume equations are used to compute total cubic feet per acre; factors are computed to convert to merchantable cubic feet and board feet. Prediction equations are included to estimate the effects of differing intensities of thinning from below and above on average diameter, average dominant and codominant height, and trees retained per acre.

Yield simulations discussed in the following paragraphs were made from the same hypothetical initial stand conditions for all growth parameters:

1. Average total age at first thinning is 30 years

2. Average stand diameter is 4.5 inches d.b.h. ${ }^{3}$

3. Stand density is 1,000 trees per acre

4. Site index is 50-, 60-, 70- and 80-foot classes, at base age 100 years (Alexander 1966)

5. Dwarf mistletoe rating is 0 (Hawksworth 1977)

6. Projections were made for 50 years (stand age 80 ) and 90 years (stand age 120)

7. Thinnings from below were made every 10,20 , and 30 years to GSL's of $40,60,80,100,120$, 140 and 160 , with initial and subsequent entries made to the same GSL

8. A clearcut option was used

9. Minimum size for inclusion in board-foot volume determinations was 6.5 inches d.b.h. to a 6-inch top

10. All thinnings were made as scheduled, even though all could be precommercial.

\section{Diameter Growth}

Periodic mean annual diameter growth of lodgepole pine is related to stand density and site quality, but is affected little by the cutting cycles tested. Cutting cycles do influence average stand diameter, however, because thinning from below increases average diameter at each entry. Actual basal area in a stand with an average diameter of less than 10 inches d.b.h. continues to increase, because periodic thinning does not reduce basal area to a fixed (GSL) amount until an average stand diameter of 10 inches d.b.h. is reached. Consequently, the rate of diameter growth for a given GSL is not constant over time and is essentially a negative exponential function of basal area per acre in the program. In contrast, periodic diameter growth is a linear function of site index, so that differences in diameter growth resulting from site quality are constant throughout the range of GSL's and rotations examined.

Growth rates and changes in diameter resulting from thinning frequency were examined to determine average size of trees relative to rotation age, site index, and stand density. For example, with a 20-year cutting cycle, trees reach average stand diameters of 7.9 to 15.3 inches d.b.h. after 80 years, and 10.1 to 24.1 inches d.b.h. after 120 years, for the range of GSL's and site indexes tested (table 1). On an average site (index 60), with a 20-year cutting cycle, trees reach 10 inches

\footnotetext{
${ }^{3}$ Average stand diameter is the diameter of the tree of average basal area; it is not the average of all the tree diameters.
}

d.b.h. at 56 to 100 years of age for the GSL range of 40 to 160 (fig. 1).

\section{Height Growth}

Periodic mean annual height growth of lodgepole pine increases with site index and decreases with age, but is influenced little by GSL's, or the cutting cycle. However, since fewer and, therefore, taller trees are left after each thinning from below, the mean height of the dominant and codominant trees is increased slightly at each entry. The increase is positively correlated with thinning frequency and negatively correlated with GSL.

\section{Basal Area Growth}

Periodic mean annual basal area increment is related to stand density, site quality, and frequency of thinning. Because actual basal area after thinning continues to increase in a stand until average stand diameter reaches 10 inches d.b.h. and thinning reduces basal area to a fixed amount (GSL), the rate of basal area growth for a given GSL is not constant over time. Periodic basal area increment is greater at higher GSL's, but the rate of increase diminishes at the higher stand densities. Periodic mean basal area growth is also greater at higher site indexes. Moreover, the dif-

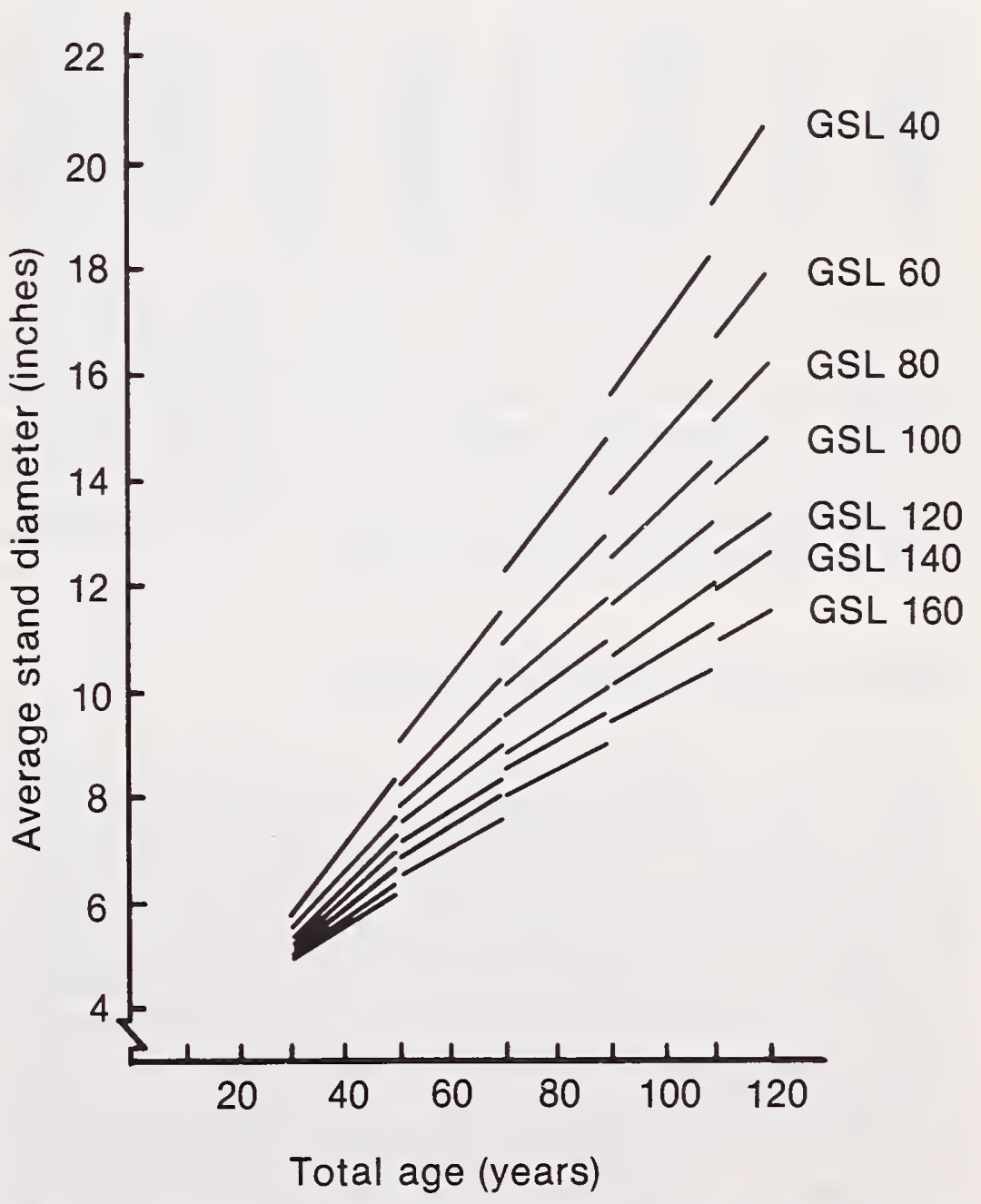

Figure 1.-Estimated average stand aımeter in relation to age and growing stock level on site index 60 lands with a 20 -year reentry schedule. 
Table 1.-Estimated average stand diameter (inches) and number of trees per acre of lodgepole pine at final harvest in relation to growing stock levels, site quality, rotation age, and cutting cycle

\begin{tabular}{|c|c|c|c|c|c|c|c|c|c|c|c|c|c|c|c|}
\hline \multirow[b]{3}{*}{$\begin{array}{c}\text { Rotation } \\
\text { age }\end{array}$} & \multirow[b]{3}{*}{$\begin{array}{c}\text { Cutting } \\
\text { cycle }\end{array}$} & \multicolumn{14}{|c|}{ Growing stock level } \\
\hline & & \multicolumn{2}{|c|}{40} & \multicolumn{2}{|c|}{60} & \multicolumn{2}{|c|}{80} & \multicolumn{2}{|c|}{100} & \multicolumn{2}{|c|}{120} & \multicolumn{2}{|c|}{140} & \multicolumn{2}{|c|}{160} \\
\hline & & Diameter & $\begin{array}{l}\text { No. of } \\
\text { trees }\end{array}$ & Diameter & $\begin{array}{l}\text { No. of } \\
\text { trees }\end{array}$ & Diameter & $\begin{array}{l}\text { No. of } \\
\text { trees }\end{array}$ & Diameter & $\begin{array}{l}\text { No. of } \\
\text { trees }\end{array}$ & Diameter & $\begin{array}{l}\text { No. of } \\
\text { trees }\end{array}$ & Diameter & $\begin{array}{l}\text { No. of } \\
\text { trees }\end{array}$ & Diameter & $\begin{array}{l}\text { No. of } \\
\text { trees }\end{array}$ \\
\hline & & \multicolumn{14}{|c|}{ Site Index 50} \\
\hline $\begin{array}{r}80 \\
120 \\
80 \\
120 \\
80 \\
120\end{array}$ & $\begin{array}{l}10 \\
20\end{array}$ & $\begin{array}{l}13.2 \\
20.9 \\
12.6 \\
19.0 \\
12.0 \\
17.2\end{array}$ & $\begin{array}{l}51 \\
19 \\
56 \\
23 \\
70 \\
39\end{array}$ & $\begin{array}{l}11.6 \\
18.0 \\
11.0 \\
16.1 \\
10.5 \\
14.7\end{array}$ & $\begin{array}{r}96 \\
39 \\
108 \\
48 \\
126 \\
76\end{array}$ & $\begin{array}{r}10.7 \\
15.9 \\
10.3 \\
14.5 \\
9.8 \\
13.2\end{array}$ & $\begin{array}{r}144 \\
65 \\
157 \\
78 \\
192 \\
121\end{array}$ & $\begin{array}{r}9.7 \\
14.2 \\
9.4 \\
13.1 \\
9.1 \\
12.0\end{array}$ & $\begin{array}{l}214 \\
101 \\
225 \\
119 \\
266 \\
176\end{array}$ & $\begin{array}{r}9.0 \\
12.6 \\
8.8 \\
11.8 \\
8.5 \\
10.9\end{array}$ & $\begin{array}{l}287 \\
153 \\
296 \\
175 \\
344 \\
243 \\
\end{array}$ & $\begin{array}{r}8.5 \\
11.9 \\
8.2 \\
10.9 \\
7.9 \\
10.0\end{array}$ & $\begin{array}{l}364 \\
197 \\
382 \\
237 \\
427 \\
320\end{array}$ & $\begin{array}{r}8.1 \\
10.7 \\
7.9 \\
10.1 \\
7.6 \\
9.2\end{array}$ & $\begin{array}{l}434 \\
276 \\
449 \\
309 \\
499 \\
390\end{array}$ \\
\hline \multicolumn{16}{|c|}{ Site Index 60} \\
\hline $\begin{array}{r}80 \\
120 \\
80 \\
120 \\
80 \\
120\end{array}$ & $\begin{array}{l}10 \\
20 \\
30\end{array}$ & $\begin{array}{l}14.4 \\
23.0 \\
13.5 \\
20.7 \\
12.7 \\
18.9\end{array}$ & $\begin{array}{l}43 \\
16 \\
49 \\
20 \\
71 \\
33\end{array}$ & $\begin{array}{l}12.8 \\
20.1 \\
12.0 \\
17.0 \\
11.4 \\
16.3\end{array}$ & $\begin{array}{r}80 \\
31 \\
93 \\
39 \\
120 \\
64\end{array}$ & $\begin{array}{l}11.5 \\
17.9 \\
11.0 \\
16.1 \\
10.4 \\
14.5\end{array}$ & $\begin{array}{r}131 \\
52 \\
144 \\
64 \\
179 \\
104\end{array}$ & $\begin{array}{r}10.8 \\
16.3 \\
10.3 \\
14.8 \\
9.8 \\
13.5\end{array}$ & $\begin{array}{r}183 \\
77 \\
199 \\
95 \\
245 \\
146\end{array}$ & $\begin{array}{r}10.2 \\
15.1 \\
9.5 \\
13.3 \\
9.1 \\
12.2\end{array}$ & $\begin{array}{l}240 \\
108 \\
272 \\
139 \\
322 \\
207\end{array}$ & $\begin{array}{r}9.4 \\
13.5 \\
9.1 \\
12.6 \\
8.7 \\
11.4\end{array}$ & $\begin{array}{l}318 \\
157 \\
334 \\
181 \\
394 \\
267\end{array}$ & $\begin{array}{r}8.8 \\
12.4 \\
8.5 \\
11.5 \\
8.2 \\
10.6\end{array}$ & $\begin{array}{l}393 \\
208 \\
413 \\
245 \\
473 \\
327\end{array}$ \\
\hline \multicolumn{16}{|c|}{ Site Index 70} \\
\hline $\begin{array}{r}80 \\
120 \\
80 \\
120\end{array}$ & $\begin{array}{l}10 \\
20\end{array}$ & $\begin{array}{l}15.2 \\
24.8 \\
14.2 \\
22.2\end{array}$ & $\begin{array}{l}39 \\
14 \\
45 \\
17\end{array}$ & $\begin{array}{l}13.7 \\
22.0 \\
12.8 \\
19.6\end{array}$ & $\begin{array}{l}72 \\
26 \\
82 \\
33\end{array}$ & $\begin{array}{l}12.5 \\
19.7 \\
11.8 \\
17.7\end{array}$ & $\begin{array}{r}113 \\
43 \\
128 \\
54\end{array}$ & $\begin{array}{l}11.7 \\
18.2 \\
11.0 \\
16.3\end{array}$ & $\begin{array}{r}160 \\
63 \\
180 \\
79\end{array}$ & $\begin{array}{l}10.9 \\
16.7 \\
10.4 \\
15.1\end{array}$ & $\begin{array}{r}216 \\
89 \\
236 \\
109\end{array}$ & $\begin{array}{l}10.4 \\
15.7 \\
10.0 \\
14.2\end{array}$ & $\begin{array}{l}276 \\
117 \\
297 \\
143\end{array}$ & $\begin{array}{r}9.9 \\
14.6 \\
9.3 \\
13.0\end{array}$ & $\begin{array}{l}338 \\
154 \\
374 \\
190\end{array}$ \\
\hline $\begin{array}{r}80 \\
120\end{array}$ & 30 & $\begin{array}{l}13.5 \\
20.5\end{array}$ & $\begin{array}{l}64 \\
29\end{array}$ & $\begin{array}{l}12.0 \\
17.7\end{array}$ & $\begin{array}{r}111 \\
56\end{array}$ & $\begin{array}{l}11.2 \\
16.1\end{array}$ & $\begin{array}{r}168 \\
88\end{array}$ & $\begin{array}{l}10.4 \\
14.8\end{array}$ & $\begin{array}{l}233 \\
127\end{array}$ & $\begin{array}{r}9.9 \\
13.8\end{array}$ & $\begin{array}{l}296 \\
172\end{array}$ & $\begin{array}{r}9.5 \\
12.9\end{array}$ & $\begin{array}{l}362 \\
217\end{array}$ & $\begin{array}{r}8.9 \\
12.0\end{array}$ & $\begin{array}{l}435 \\
276\end{array}$ \\
\hline \multicolumn{16}{|c|}{ Site Index 80} \\
\hline $\begin{array}{r}80 \\
120 \\
80 \\
120 \\
80 \\
120\end{array}$ & 20 & $\begin{array}{l}16.3 \\
26.8 \\
15.3 \\
24.1 \\
14.5 \\
22.1\end{array}$ & $\begin{array}{l}34 \\
12 \\
40 \\
15 \\
56 \\
25\end{array}$ & $\begin{array}{l}14.7 \\
23.7 \\
13.8 \\
21.3 \\
13.1 \\
19.7\end{array}$ & $\begin{array}{r}62 \\
23 \\
72 \\
28 \\
102 \\
46\end{array}$ & $\begin{array}{l}13.5 \\
21.6 \\
12.6 \\
19.3 \\
11.8 \\
17.3\end{array}$ & $\begin{array}{r}99 \\
36 \\
113 \\
46 \\
157 \\
79\end{array}$ & $\begin{array}{l}12.8 \\
20.3 \\
12.0 \\
18.0 \\
11.2 \\
16.2\end{array}$ & $\begin{array}{r}134 \\
51 \\
154 \\
65 \\
214 \\
110\end{array}$ & $\begin{array}{l}12.0 \\
18.6 \\
11.3 \\
16.9 \\
10.9 \\
15.2\end{array}$ & $\begin{array}{r}182 \\
73 \\
207 \\
88 \\
262 \\
125\end{array}$ & $\begin{array}{l}11.3 \\
17.6 \\
10.6 \\
15.7 \\
10.1 \\
14.2\end{array}$ & $\begin{array}{r}237 \\
94 \\
270 \\
119 \\
338 \\
180\end{array}$ & $\begin{array}{r}10.4 \\
16.4 \\
10.0 \\
14.9 \\
9.7 \\
13.6\end{array}$ & $\begin{array}{l}298 \\
114 \\
320 \\
143 \\
400 \\
225\end{array}$ \\
\hline
\end{tabular}

ferences in basal area growth between site classes become progressively greater with higher GSL's. Periodic mean basal area increment is greater with a 30-year cutting cycle than with more frequent entries at all growing stock levels examined.

\section{Total Cubic-Foot Volume Increment}

Cubic-foot volume production is related to stand density, site quality, rotation age, and frequency of thinning (table 2). Although mean annual cubic volume increment increases as GSL and site index increase, the rate of increase diminishes as GSL increases, while the differences in growth between site classes become greater (fig. 2). Cubic volume increment will apparently continue to increase slightly at GSL's above 160 when site index is 70 or greater. At GSL's higher than 120 , there is no difference in total cubic-foot volume production between a 20- and a 30-year cycle (table 2). Cubicvolume growth is unrelated to length of rotation, but at GSL's up to 120 it is greater with a 30-year cutting cycle than with a shorter one (table A-4).

\section{Board-Foot Volume Increment}

Board-foot volume production is related to all stand parameters evaluated (table 3). Mean annual sawtimber volume increases throughout the range of GSL's tested on site index 70 and 80 lands, but generally levels off or declines at GSL's 140 and above on the poorer sites (fig. 3, table A-5). Board-foot volume growth increases with site quality, and the differences in growth between site classes becomes greater as GSL increases. Throughout the range of GSL's, average annual board-foot increment per acre is always greater for a given site class on a 120-year rotation than on an 80-year rotation (fig. 4).

At GSL's 40 to 100 , board-foot growth is greater on a 30-year cutting cycle, but with heavier stocking, growth is greater with more frequent thinnings (fig. 5).

\section{Maximizing Board-Foot Volume Yields}

What yields can be expected with intensive management of lodgepole pine to maximize timber production? 
Table 2.-Estimated total cubic-foot volume production per acre of lodgepole pine in relation to growing stock levels, site quality, rotation age, and cutting cycle

\begin{tabular}{lllllllll}
\hline $\begin{array}{l}\text { Rotation } \\
\text { age }\end{array}$ & $\begin{array}{c}\text { Cutting } \\
\text { cycle }\end{array}$ & \multicolumn{6}{c}{ Growing stock level } \\
\cline { 3 - 8 } & & 40 & 60 & 80 & 100 & 120 & 140 & 160 \\
\hline
\end{tabular}

Site Index 50

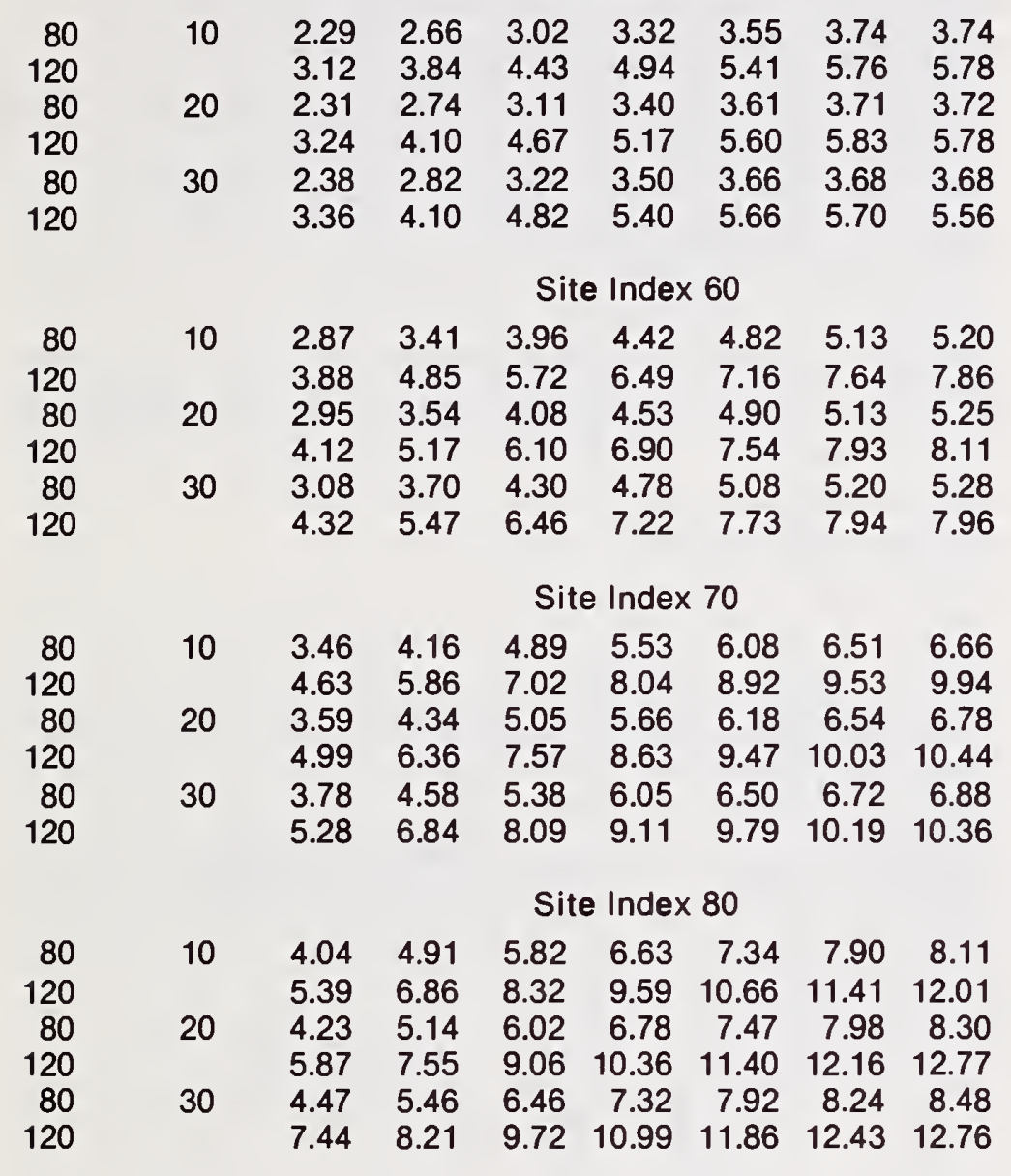

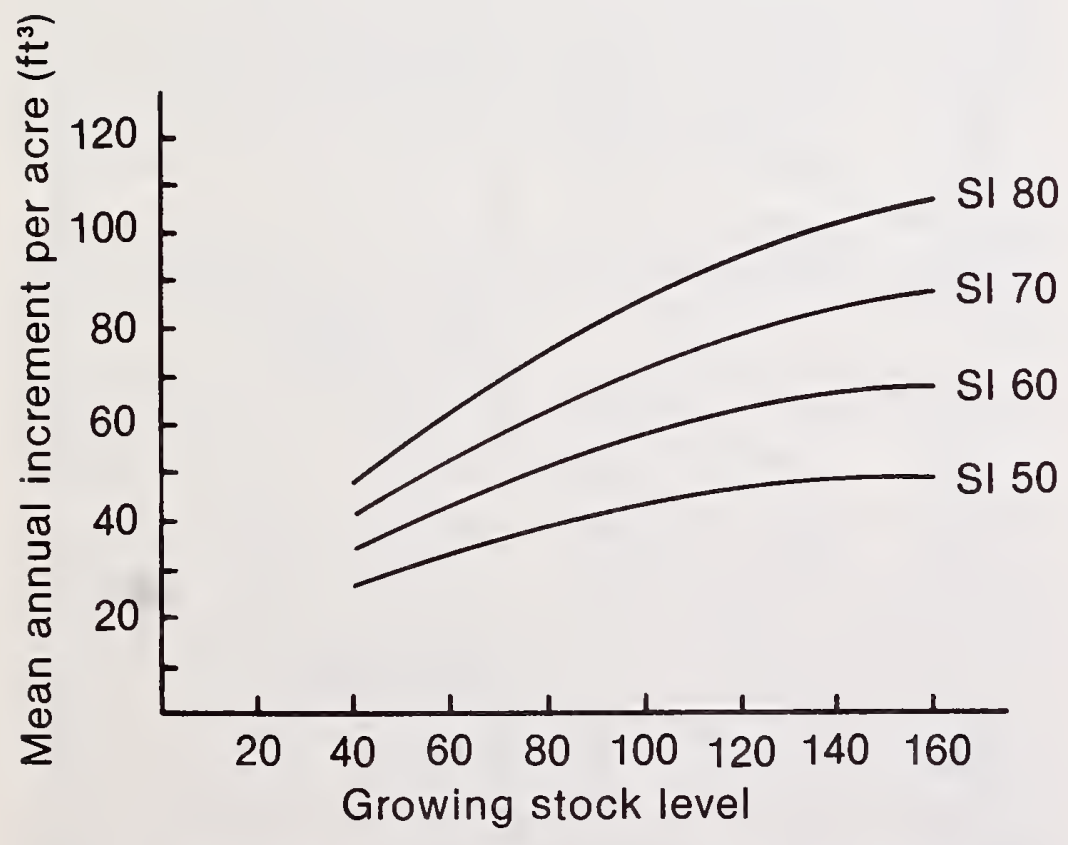

Figure 2.-Estimated mean annual total cubic-foot volume increment per acre in relation to growing stock level and site quality for a 120-year rotation with a 20-year reentry schedule.
Table 3.-Estimated board-foot volume production per acre of lodgepole pine in relation to growing stock levels, site quality, rotation age, and cutting cycle (trees 6.5 inches d.b.h. to a 6-inch top)

\begin{tabular}{ccccccccc}
\hline $\begin{array}{c}\text { Rotation } \\
\text { age }\end{array}$ & $\begin{array}{c}\text { Cutting } \\
\text { cycle }\end{array}$ & 40 & 60 & 80 & 100 & 120 & 140 & 160
\end{tabular}

years …................... thousand board feet

Site Index 50

\begin{tabular}{rrrrrrrrr}
80 & 10 & 6.1 & 7.6 & 9.0 & 9.9 & 10.8 & 11.4 & 11.8 \\
120 & & 10.6 & 13.4 & 16.1 & 17.9 & 19.3 & 20.6 & 20.8 \\
80 & 20 & 6.0 & 7.6 & 9.2 & 10.4 & 10.7 & 11.0 & 10 \\
120 & & 10.9 & 13.9 & 16.4 & 18.8 & 19.7 & 20.4 & 19.9 \\
80 & 30 & 6.9 & 8.5 & 9.4 & 9.8 & 10.0 & 0 & 0 \\
120 & & 12.0 & 15.0 & 16.8 & 18.6 & 19.2 & 19.2 & 19.0 \\
& & \multicolumn{7}{c}{ Site Index 60} \\
80 & \multirow{2}{*}{10} & 7.8 & 10.0 & 12.2 & 13.9 & 15.6 & 16.9 & 17.8 \\
120 & & 13.6 & 17.6 & 21.5 & 24.5 & 27.1 & 29.0 & 29.8 \\
80 & 20 & 8.2 & 10.4 & 12.6 & 14.4 & 15.5 & 16.6 & 16.8 \\
120 & & 14.5 & 18.7 & 22.6 & 25.8 & 28.1 & 29.8 & 30.1 \\
80 & 30 & 9.3 & 11.7 & 13.4 & 14.6 & 15.2 & 15.6 & 15.8 \\
120 & & 16.2 & 20.4 & 24.0 & 26.4 & 27.6 & 28.2 & 28.6
\end{tabular}

Site Index 70

$\begin{array}{rrrrrrrrr}80 & 10 & 9.6 & 12.4 & 15.4 & 17.9 & 20.4 & 22.4 & 23.8 \\ 120 & & 16.6 & 21.8 & 26.9 & 31.1 & 34.9 & 37.4 & 38.8 \\ 80 & 20 & 10.3 & 13.2 & 15.9 & 18.4 & 20.3 & 22.1 & 23.2 \\ 120 & & 18.1 & 23.5 & 28.7 & 33.5 & 36.5 & 39.0 & 40.3 \\ 80 & 30 & 11.7 & 14.9 & 17.4 & 19.4 & 20.4 & 21.2 & 21.4 \\ 120 & & 20.4 & 26.4 & 31.2 & 34.2 & 36.0 & 37.2 & 38.2\end{array}$

Site Index 80

$\begin{array}{rllllllll}80 & 10 & 11.4 & 17.4 & 18.6 & 21.9 & 25.2 & 27.9 & 29.8 \\ 120 & & 19.6 & 26.0 & 32.3 & 37.7 & 42.7 & 45.8 & 47.8 \\ 80 & 20 & 12.5 & 16.0 & 19.3 & 22.4 & 25.1 & 27.6 & 29.6 \\ 120 & & 21.7 & 28.3 & 34.8 & 40.8 & 44.9 & 48.2 & 50.5 \\ 80 & 30 & 14.1 & 18.1 & 21.4 & 24.2 & 25.6 & 26.8 & 27.0 \\ 120 & & 24.6 & 32.4 & 38.4 & 42.0 & 44.4 & 46.2 & 47.8\end{array}$

'Stand board-foot volume is not computed when average stand d.b.h. is less than 8.0 inches.

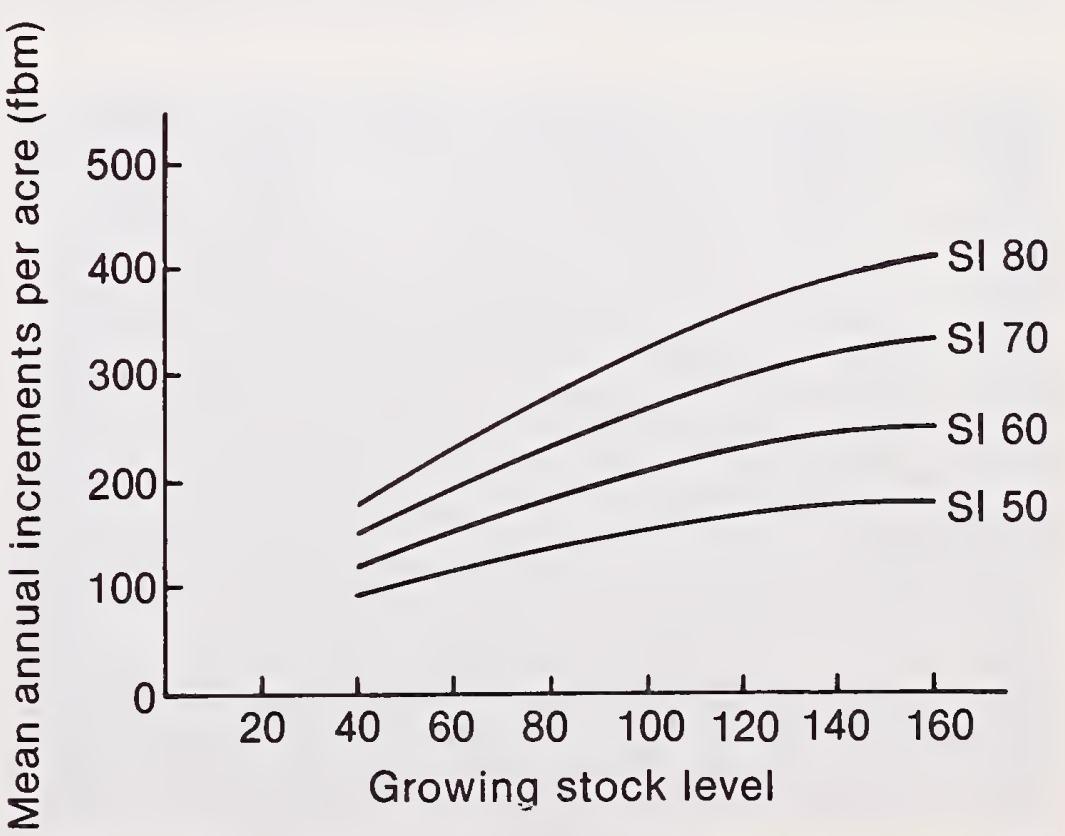

Figure 3.- Estimated mean annual board-foot volume increment per acre in relation to growing stock level and site quality for a 120-year rotation with a 20-year reentry schedule. 


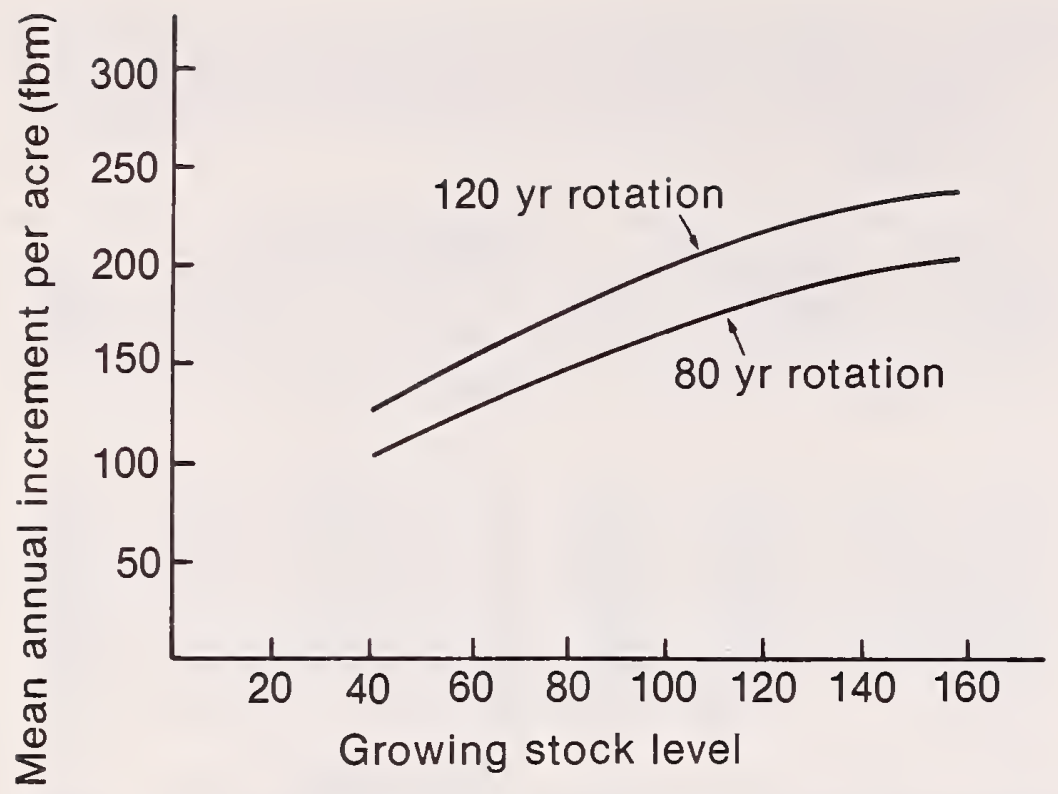

Figure 4.- Estimated mean annual board-foot increment per acre on site index 60 lands with a 20-year reentry schedule in relation to growing stock level and rotation age.

If the objective is to integrate timber production with other resource uses, what are the timber tradeoffs? How can these objectives be attained with the fewest precommercial thinnings?

Large volume production per acre, 50,500 board feet, is attained on site index 80 lands, at GSL 160, with a 120-year rotation, and a 20-year cutting cycle (table 3). These stands will contain about 140 trees per acre with an average diameter of nearly 15 inches d.b.h. at rotation age (table 1 ).

Volume production substantially declines when GSL is reduced. The decline is greater with each successive reduction. At site index 60 and 70, largest volume production also occurs at GSL 160, with a 120 -year rotation and a 20-year cutting cycle, but at site index 50, the greatest production is at GSL 140, with GSL's 100 and 120 nearly as favorable.

Table 3 also shows the amount of volume given up as GSL is reduced from 160 to 40 for all combinations of

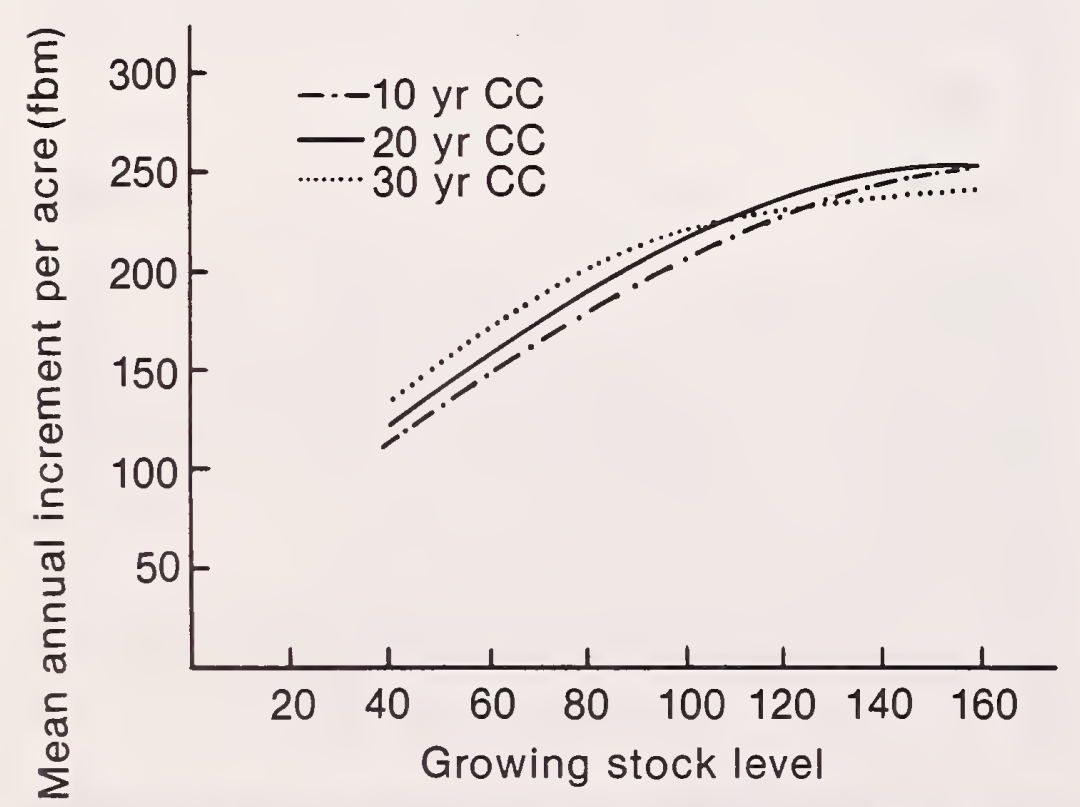

Figure 5. - Estimated mean annual board-foot increment per acre in relation to reentry schedules on site index 60 lands.

stand parameters examined. Moreover, it shows that more volume can be produced over the same time span with 120-year rotations than with 80 -year rotations. For example, on-site index 80 lands, maximum boardfoot volume production per acre for two 120-year rotations, or 240 years, would be $101,000 \mathrm{fbm}$, compared with $89,400 \mathrm{fbm}$ on three 80 -year rotations, also 240 years.

Whether the board-foot volume potentials can be achieved depends largely on how much money can be invested in thinning. It is assumed that once a stand reaches a minimum merchantable size of 6.5 inches average d.b.h. to a 6-inch top, market conditions permit intermediate thinnings to be made as scheduled. If economic constraints allow only one precommercial thinning in the life of the stand, the manager's options are severely restricted. For example, at site index 50 and 60 , the stand density must be reduced to a GSL of 60 , and the cutting cycle increased to 30 years (table 4). At site index 70 , stand density must be reduced to a GSL of 80; and at index 80, where there is more flexibility, a GSL of 120 can be maintained with a 30-year cutting cycle (fig. 6).

Table 4.- Number of precommercial thinnings of lodgepole pine in relation to growing stock levels, site quality, rotation age, and cutting cycle

\begin{tabular}{lllllllll}
\hline Cutting & Site \\
cycle & index & 40 & 60 & 80 & 100 & 120 & 140 & 160 \\
\cline { 5 - 8 }
\end{tabular}

years

\begin{tabular}{rllllllll}
\multicolumn{8}{c}{ Site Index 50} \\
80 & 10 & 2 & 3 & 3 & 4 & 4 & 5 & 5 \\
120 & & 2 & 3 & 3 & 4 & 4 & 5 & 5 \\
80 & 20 & 1 & 2 & 2 & 2 & 3 & 3 & 3 \\
120 & & 1 & 2 & 2 & 2 & 3 & 3 & 3 \\
80 & 30 & 1 & 1 & 2 & 2 & 2 & 2 & 3 \\
120 & & 1 & 1 & 2 & 2 & 2 & 2 & 3
\end{tabular}

$\begin{array}{rllllllll}80 & 10 & 2 & 2 & 3 & 3 & 3 & 4 & 4 \\ 120 & & 2 & 2 & 3 & 3 & 3 & 4 & 4 \\ 80 & 20 & 1 & 2 & 2 & 2 & 2 & 2 & 3 \\ 120 & & 1 & 2 & 2 & 2 & 2 & 2 & 3 \\ 80 & 30 & 1 & 1 & 2 & 2 & 2 & 2 & 3 \\ 120 & & 1 & 1 & 2 & 2 & 2 & 2 & 3\end{array}$

\begin{tabular}{rllllllll}
80 & 10 & 2 & 2 & 3 & 3 & 3 & 3 & 4 \\
120 & & 2 & 2 & 3 & 3 & 3 & 3 & 4 \\
80 & 20 & 1 & 2 & 2 & 2 & 2 & 2 & 2 \\
120 & & 1 & 2 & 2 & 2 & 2 & 2 & 2 \\
80 & 30 & 1 & 1 & 1 & 2 & 2 & 2 & 2 \\
120 & & 1 & 1 & 1 & 2 & 2 & 2 & 2 \\
\multicolumn{7}{c}{ Site Index 80} \\
80 & 10 & 2 & 2 & 2 & 3 & 3 & 3 & 3 \\
120 & & 2 & 2 & 2 & 3 & 3 & 3 & 3 \\
80 & 20 & 1 & 1 & 2 & 2 & 2 & 2 & 2 \\
120 & & 1 & 1 & 2 & 2 & 2 & 2 & 2 \\
80 & 30 & 1 & 1 & 1 & 1 & 1 & 2 & 2 \\
120 & & 1 & 1 & 1 & 1 & 1 & 2 & 2
\end{tabular}




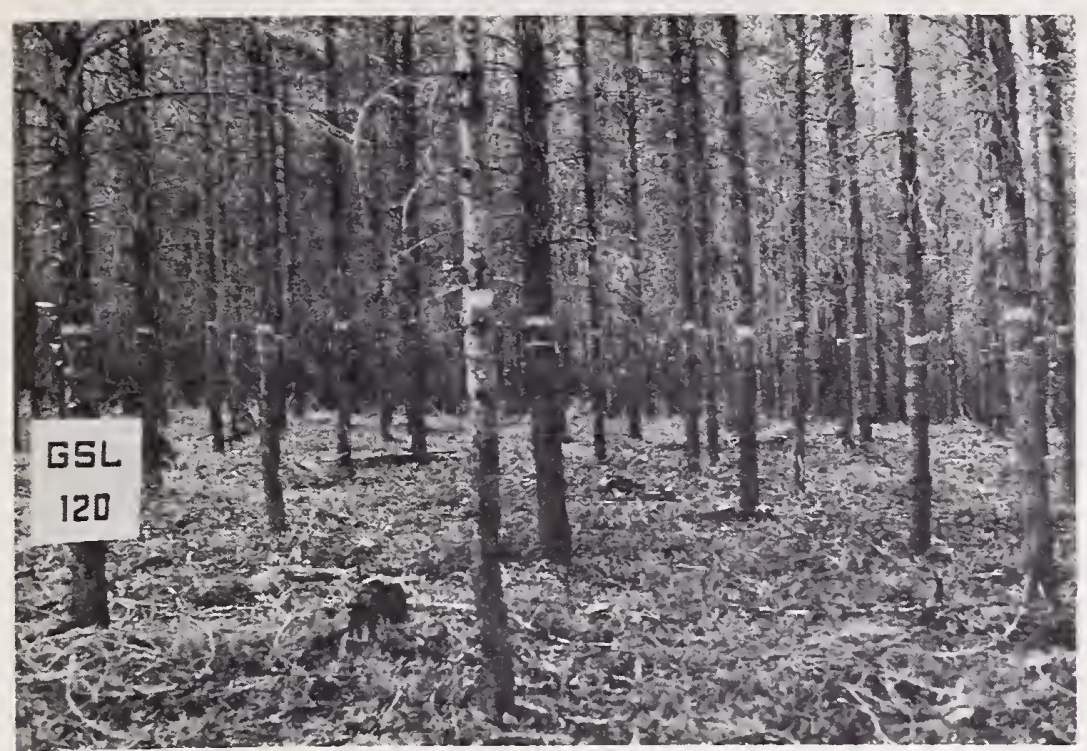

Figure 6.-Second-growth lodgepole pine on site index 80 lands thinned to GSL 120, Fraser Experimental Forest, Colorado. Stand was about 60 years old when thinned in 1976.

Thinnings to a constant GSL have been assumed up to this point. However, if only one precommercial thinning is possible, managers can increase their flexibility by changing GSL's with successive thinnings. For example, on site index 70 lands, with a 30-year cutting cycle, GSL may be initially reduced to 80 but increased to 100 at the second thinning, and to 120 at the third thinning. Volume production will be less than maximum, but reasonably close to that available from a stand maintained at a constant GSL 120. Attempts to raise the GSL to 120 at the time of the second entry into the stand would result in a second precommercial thinning. By following this procedure, managers can increase GSL on site index 50 and 60 lands from 60 to 100 .

The manager has another option if only one precommercial thinning is possible. The initial thinning can be made on schedule and the second entry delayed until the stand reaches minimum merchantable size. This will increase the second thinning interval to 40 years or more, increase the length of the rotation, and result in less than maximum volume production.

Where economic conditions permit two precommercial thinnings, the manager has the flexibility to maximize timber production on site index 60,70 , and 80 lands. On site index 50 lands, a GSL of 100 could be maintained, or it could be increased to GSL 140 by changing levels with successive reentries.

Managers may also elect to change GSL's with successive reentries regardless of the number of precommerical thinnings that are economically possible. With this procedure, the concern about retaining many trees early in the life of the stand, and fewer trees later in the rotation can be avoided. For example, stand density can be initially reduced to GSL's 60 to 100 and successively increased to GSL's 120 to 160, depending upon site quality and cutting cycle. Volume production will be less than if stand density were maintained at a constant and higher, initial GSL, however.

\section{Tradeoffs to Increase Values of Other Resources}

Understory vegetation in lodgepole pine forests is potentially important as forage for big game and livestock, but as overstory density increases, the productivity of the understory decreases. This relationship is generally shown to be curvilinear (Basile 1975). To increase forage, the manager must be willing to reduce timber production. For example, clearcutting old-growth stands to bring them under management increases the amount of understory (Trappe and Harris 1958, Basile and Jensen 1971, Regelin and Wallmo 1978). The changes in species composition and palatability vary considerably, depending upon habitat type. The changes in production and composition persist for 10 to 20 years before competition from tree reproduction begins to reduce understory vegetation. Thinning second-growth lodgepole pine also increases the amount and changes the composition of understory species (Dealy 1975). These changes are generally greatest in low-density stands.

Although no methods or data are available to quantify changes in understory herbage production under lodgepole pine, for the range of GSL's, site indexes, rotation ages, and cutting cycles examined here, some general conclusions can be drawn. To increase average herbage production to even moderate levels, the manager must be willing to reduce basal area stocking per acre to GSL 60 or less (fig. 7). To maintain forage production, the manager must be able to make additional cuts in the stand at intervals of at least every 20 years.

Lodgepole pine forests are important water-yielding areas in the Rocky Mountains. The proportion of water yield to precipitation is high because of the cold climate, short growing season, and the accumulation of an overwinter snowpack (Hoover 1975). Because most of the water available for streamflow comes from snowmelt, the most efficient pattern of timber harvest

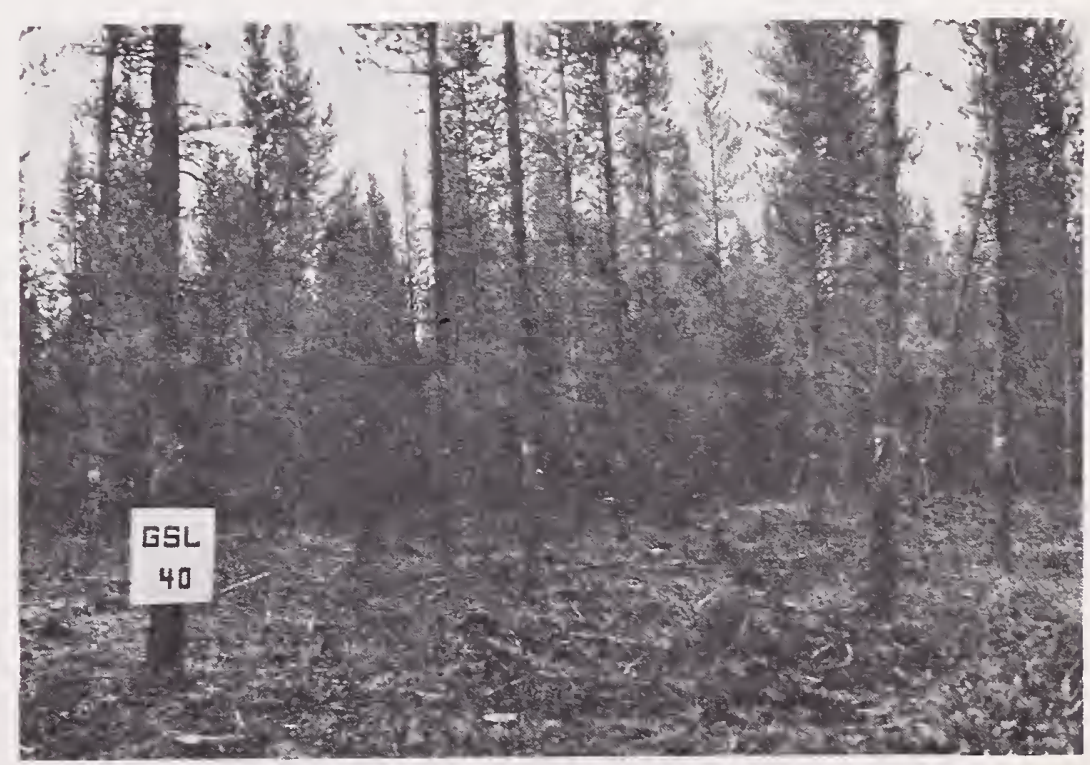

Figure 7.-Second-growth lodgepole pine on site index 80 lands thinned to GSL 40, Fraser Experimental Forest, Colorado. Stand was about 60 years old when thinned in 1976. 
for water yield in old-growth stands is to clearcut about $30-40 \%$ of a drainage (1) in small, irregularshaped patches about five to eight times tree height in diameter, (2) protected from the wind, and (3) interspersed with uncut patches of about the same size (Leaf 1975). Leaf and Alexander (1975) used simulations generated by hydrologic and timber yield models (Myers et al. 197l, Leaf and Brink 1973, Edminster 1978) to estimate water available for streamflow on lands where lodgepole pine had been clearcut and the regenerated stand was being managed under various alternatives. Figure 8 shows projected water yield increases over a 120-year rotation, at GSL 100, on a 30-year cutting cycle, on site index 60 lands. Simulation also showed that estimated water yield was influenced little by any combination of initial and subsequent GSL's in managed stands that ranged from 80 to 120 . More water should be available for streamflow at lower stand densities because of the reduction in consumptive use by trees, but no comparisons were made at higher or lower densities. One unknown factor is water use by competing understory vegetation associated with different habitat types for different GSL's.

Information from research and simulation makes clear that stand density must be substantially reduced to and maintained at a low GSL to benefit water and forage resources. Amenity values and recreational opportunities are generally improved only at low stocking. But considerable timber volume production is given up at low stand densities. For example, on-site index 80 lands, at GSL 60, with a 120 -year rotation and a 20-year thinning schedule, yield is $28,300 \mathrm{fbm}$ per acre or 22,200 fewer than the $50,500 \mathrm{fbm}$ produced at GSL 160 . If the GSL is reduced to 40 , the loss in volume production is $28,800 \mathrm{fbm}$ per acre (table 3 ).

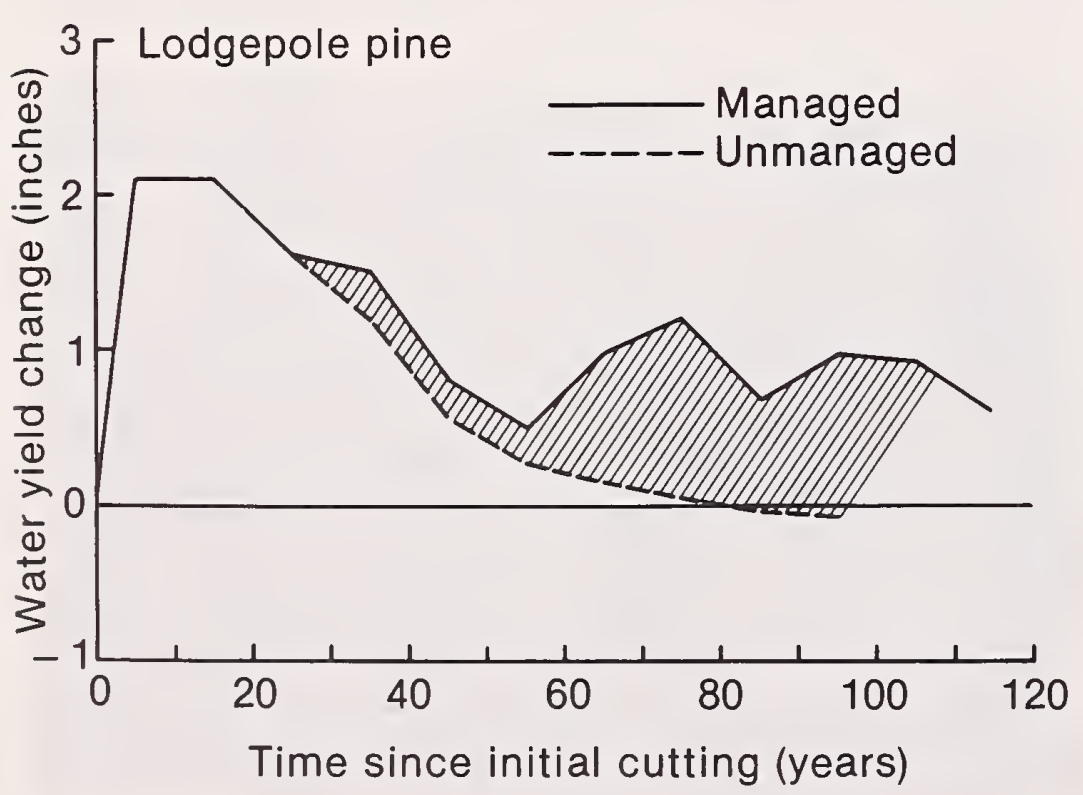

Figure 8.-Projected changes in annual water yield from simula. tion for GSL 100 on site index 60 lands, with a 30-year cutting cycle, and a 120-year rotation (Leaf and Alexander 1975).

\section{Management Caution}

This simulation program provides growth estimates that appear reasonable and consistent within the limits of current knowledge, but no lodgepole pine stand has been under management for a long time, and simulation extends beyond the limits of the available data base. Comparisons of estimates with actual values from plots established to provide growth information will be needed to verify simulated responses.

\section{Literature Cited}

Alexander, Robert R. 1960. Thinning lodgepole pine in the central Rocky Mountains. Journal of Forestry 58:99-104.

Alexander, Robert R. 1965. Growth of thinned young lodgepole pine in Colorado. Journal of Forestry 63:429-433.

Alexander Robert R. 1966. Site indexes for lodgepole pine, with corrections for stand density: Instruction for field use. USDA Forest Service Research Paper RM-24, 7 p. Rocky Mountain Forest and Range Experiment Station, Fort Collins, Colo.

Alexander, Robert R. 1974. Silviculture of subalpine coniferous forests in the central and southern Rocky Mountains: The status of our knowledge. USDA Forest Service Research Paper RM-121, 88 p. Rocky Mountain Forest and Range Experiment Station, Fort Collins, Colo.

Alexander, Robert R. 1975. Partial cutting in oldgrowth lodgepole pine. USDA Forest Service Research Paper RM-135, 17 p. Rocky Mountain Forest and Range Experiment Station, Fort Collins, Colo.

Basile, J. V. 1975. Forage productivity in the lodgepole pine type. p. 246-263. In Proceedings of Management of Lodgepole Pine Ecosystems Symposium. 2 volumes. D. M. Baumgartner, editor. Washington State University, Cooperative Extension Service, Pullman.

Basile, J. V., and C. E. Jensen, 1971. Grazing potential on lodgepole pine clearcuts in Montana. USDA Forest Service Research Paper. INT-98, 11 p. Intermountain Forest and Range Experiment Station, Ogden, Utah.

Boe, Kenneth N. 1956. Regeneration and slash disposal in lodgepole clearcuttings. Northwest Science 30:1-11.

Choate, G. A. 1963. The forests of Wyoming. USDA Forest Service Resource Bulletin INT-2, 45 p. Intermountain Forest and Range Experiment Station, Ogden, Utah.

Dahms, Walter G. 1963. Dispersal of lodgepole pine into clear-cut patches. U. S. Forest Service Research Note PNW-3, 7 p. Pacific Northwest Forest and Range Experiment Station, Portland, Oreg. 
Dealy, J. E. 1975. Management of lodgepole pine ecosystems for range and wildlife. p. 556-568. In Proceedings of Management of Lodgepole Pine Ecosystems Symposium. 2 volumes. D. M. Baumgartner, editor. Washington State University, Cooperative Extension Service, Pullman.

Edminster, C. B. 1978 RMYLD. Computation of yield tables for even- aged and two-storied stands. USDA Forest Service Research Paper RM-199, 26 p. Rocky Mountain Forest and Range Experiment Station, Fort Collins, Colo.

Hawksworth, F. G. 1977. The 6-class dwarf mistletoe rating system. USDA Forest Service General Technical Report RM-48, 7 p. Rocky Mountain Forest and Range Experiment Station, Fort Collins, Colo.

Hoover, M. D. 1975. Watershed management in lodgepole pine ecosystems. p. 569-580. In Proceedings of Management of Lodgepole Pine Ecosystems Symposium. 2 volumes. D. M. Baumgartner, editor. Washington State University, Cooperative Extension Service, Pullman.

Leaf, C. F. 1975. Watershed management in the Rocky Mountain subalpine zone: The status of our knowledge. USDA Forest Service Research Paper RM-137, 31 p. Rocky Mountain Forest and Range Experiment Station, Fort Collins, Colo.

Leaf, C. F., and G. F. Brink. 1973. Hydrologic simulation model of Colorado subalpine forest. USDA Forest Service Research Paper RM-107, 23 p. Rocky Mountain Forest and Range Experiment Station, Fort Collins, Colo.
Leaf, C. F., and R. R. Alexander. 1975. Simulating timber yields and hydrologic impacts resulting from timber harvest on subalpine watershed. USDA Forest Service Research Paper RM-133, 20 p. Rocky Mountain Forest and Range Experiment Station, Fort Collins, Colo.

Miller, R. L., and G. A. Choate. 1964. The forest resource of Colorado. USDA Forest Service Resource Bulletin INT-3, 55 p. Intermountain Forest and Range Experiment Station, Ogden, Utah.

Myers, C. A. 1971. Field and computer procedures for managed-stand yield tables. USDA Forest Service Research Paper RM-79, 24 p. Rocky Mountain Forest and Range Experiment Station, Fort Collins, Colo.

Myers, C. A., F. G. Hawksworth, and J. L. Stewart. 1971. Simulating yields of managed, dwarf mistletoeinfested lodgepole pine stands. USDA Forest Service Research Paper RM-72, 15 p. Rocky Mountain Forest and Range Experiment Station, Fort Collins, Colo.

Regelin, W. L., and O. C. Wallmo. 1978. Duration of deer forage benefits after clearcut logging of subalpine forest in Colorado. USDA Forest Service Research Note RM-356, 4 p. Rocky Mountain Forest and Range Experiment Station, Fort Collins, Colo.

Tackle, David. 1964. Regenerating lodgepole pine in central Montana following clearcutting. U.S. Forest Service Research Note INT-17, 7 p. Intermountain Forest and Range Experiment Station, Ogden, Utah.

Trappe, J. M., and R. W. Harris. 1958. Lodgepole pine in the Blue Mountains of northeastern Oregon. USDA Forest Service, Pacific Northwest Forest and Range Experiment Station, Station Paper 30, 22 p. 


\section{Appendix}

Table A-1.-Basal areas (square feet per acre) after intermediate cutting in relation to average diameter (inches) and growing stock level

\begin{tabular}{crrrrrrr}
\hline $\begin{array}{c}\text { Average stand } \\
\text { d.b.h. after } \\
\text { cutting }\end{array}$ & $\mathbf{6 0}$ & $\mathbf{6 0}$ & $\mathbf{8 0}$ & 100 & 120 & 140 & 160 \\
\cline { 2 - 7 } & 3.0 & 4.5 & 6.0 & 7.5 & 9.0 & 10.5 & 12.0 \\
\hline 1.0 & 6.0 & 9.1 & 12.1 & 15.1 & 18.2 & 21.2 & 24.2 \\
2.0 & 11.8 & 17.8 & 23.7 & 29.6 & 35.6 & 41.5 & 47.4 \\
3.0 & 17.6 & 26.4 & 35.2 & 44.0 & 52.8 & 61.6 & 70.4 \\
4.0 & 23.4 & 35.1 & 46.8 & 58.5 & 70.2 & 81.9 & 93.6 \\
5.0 & 28.3 & 42.4 & 56.6 & 70.8 & 84.9 & 99.0 & 113.2 \\
6.0 & 32.7 & 49.0 & 65.4 & 81.8 & 98.1 & 114.4 & 130.8 \\
7.0 & 36.2 & 54.4 & 72.5 & 90.6 & 108.8 & 126.9 & 145.0 \\
8.0 & 38.8 & 58.1 & 77.5 & 96.9 & 116.2 & 135.6 & 155.0 \\
9.0 & 40.0 & 60.0 & 80.0 & 100.0 & 120.0 & 140.0 & 160.0 \\
$10.0^{+}$ & & & & & & & \\
\hline
\end{tabular}

Table A-2. - Number of residual stems per acre after intermediate cutting in relation to average diameter (inches) and growing stock level

\begin{tabular}{crrrrrrr}
\hline $\begin{array}{c}\text { Average stand } \\
\text { d.b.h. after } \\
\text { cutting }\end{array}$ & $\mathbf{8 0}$ & $\mathbf{6 0}$ & 80 & 100 & 120 & 140 & 160 \\
\cline { 2 - 8 } & 553 & 830 & 1,107 & 1,383 & 1,660 & 1,937 & 2,213 \\
1.0 & 277 & 415 & 553 & 692 & 830 & 968 & 1,107 \\
2.0 & 241 & 361 & 482 & 602 & 723 & 843 & 964 \\
3.0 & 202 & 303 & 404 & 505 & 606 & 707 & 808 \\
4.0 & 172 & 258 & 343 & 429 & 515 & 601 & 687 \\
5.0 & 144 & 216 & 288 & 361 & 433 & 505 & 577 \\
6.0 & 122 & 184 & 245 & 306 & 367 & 428 & 489 \\
7.0 & 104 & 156 & 208 & 260 & 312 & 364 & 415 \\
8.0 & 88 & 132 & 175 & 219 & 263 & 307 & 351 \\
9.0 & 73 & 110 & 147 & 183 & 220 & 257 & 293 \\
10.0 & & & & & & & \\
\hline
\end{tabular}

Table A-3.-Average distance (feet) between residual trees after intermediate cutting in relation to average diameter (inches) and growing stock level

\begin{tabular}{|c|c|c|c|c|c|c|c|}
\hline \multirow{2}{*}{$\begin{array}{l}\text { Average stand } \\
\text { d.b.h. after } \\
\text { cutting }\end{array}$} & \multicolumn{7}{|c|}{ Growing stock level } \\
\hline & 40 & 60 & 80 & 100 & 120 & 140 & 160 \\
\hline 1.0 & 8.9 & 7.3 & 6.3 & 5.6 & 5.1 & 4.8 & 4.4 \\
\hline 2.0 & 12.5 & 10.2 & 8.9 & 7.9 & 7.2 & 6.7 & 6.3 \\
\hline 3.0 & 13.4 & 11.0 & 9.5 & 8.5 & 7.8 & 7.2 & 6.7 \\
\hline 4.0 & 14.7 & 12.0 & 10.4 & 9.3 & 8.5 & 7.9 & 7.3 \\
\hline 5.0 & 15.9 & 13.0 & 11.3 & 10.1 & 9.2 & 8.5 & 8.0 \\
\hline 6.0 & 17.4 & 14.2 & 12.3 & 11.0 & 10.0 & 9.3 & 8.7 \\
\hline 7.0 & 18.9 & 15.4 & 13.3 & 11.9 & 10.9 & 10.1 & 9.4 \\
\hline 8.0 & 20.5 & 16.7 & 14.5 & 13.0 & 11.8 & 10.9 & 10.2 \\
\hline 9.0 & 22.3 & 18.2 & 15.8 & 14.1 & 12.9 & 11.9 & 11.1 \\
\hline 10.0 & 24.4 & 19.9 & 17.2 & 15.4 & 14.1 & 13.0 & 12.2 \\
\hline
\end{tabular}


Table A-4. - Estimated mean annual total cubic-foot volume increment per acre of lodgepole pine in relation to growing stock level, site quality, rotation ages, and cutting cycle
Table A-5. - Estimated mean annual board-foot volume increment per acre of lodgepole pine in relation to growing stock levels, site quality, rotation age, and cutting cycle (trees 6.5 inches d.b.h. to a 6 -inch top)

\begin{tabular}{lcccccccc}
\hline $\begin{array}{c}\text { Rotation } \\
\text { age }\end{array}$ & $\begin{array}{c}\text { Cutting } \\
\text { cycle }\end{array}$ & 40 & 60 & 80 & 100 & 120 & 140 & 160 \\
\hline
\end{tabular}

\begin{tabular}{|c|c|c|c|c|c|c|c|c|}
\hline \multirow{2}{*}{$\begin{array}{r}80 \\
120\end{array}$} & \multirow[b]{2}{*}{10} & \multicolumn{7}{|c|}{ Site Index 50} \\
\hline & & $\begin{array}{l}28.6 \\
26.0\end{array}$ & $\begin{array}{l}33.2 \\
32.0\end{array}$ & $\begin{array}{l}37.9 \\
36.9\end{array}$ & $\begin{array}{l}41.5 \\
41.2\end{array}$ & $\begin{array}{l}44.4 \\
45.1\end{array}$ & $\begin{array}{l}46.8 \\
48.0\end{array}$ & $\begin{array}{l}46.8 \\
48.2\end{array}$ \\
\hline 80 & 20 & 28.9 & 34.2 & 38.9 & 42.5 & 45.1 & 46.4 & 46.5 \\
\hline 120 & & 27.0 & 33.2 & 38.4 & 43.1 & 46.7 & 48.6 & 48.2 \\
\hline 80 & 30 & 29.8 & 35.2 & 40.3 & 43.8 & 45.8 & 46.0 & 46.0 \\
\hline 120 & & 28.0 & 34.2 & 40.2 & 45.0 & 47.2 & 47.5 & 46.3 \\
\hline
\end{tabular}

Site Index 60

$\begin{array}{rllllllll}80 & 10 & 35.9 & 42.6 & 49.5 & 55.3 & 60.2 & 64.1 & 65.0 \\ 120 & & 32.3 & 40.4 & 47.7 & 54.1 & 59.7 & 63.7 & 65.5 \\ 80 & 20 & 36.9 & 44.2 & 51.0 & 56.6 & 61.2 & 64.1 & 65.6 \\ 120 & & 34.3 & 43.1 & 50.8 & 57.5 & 67.8 & 66.1 & 67.6 \\ 80 & 30 & 38.5 & 46.2 & 53.8 & 59.7 & 63.5 & 65.0 & 66.0 \\ 120 & & 36.0 & 45.6 & 53.8 & 60.2 & 64.4 & 66.2 & 66.3\end{array}$

Site Index 70

$\begin{array}{rllllllll}80 & 10 & 43.2 & 52.0 & 61.1 & 69.1 & 76.0 & 81.4 & 83.2 \\ 120 & & 38.6 & 48.8 & 58.5 & 67.0 & 74.3 & 79.4 & 82.8 \\ 80 & 20 & 44.9 & 54.2 & 63.1 & 70.7 & 77.3 & 81.8 & 84.7 \\ 120 & & 41.6 & 53.0 & 63.1 & 71.9 & 78.9 & 83.6 & 87.0 \\ 80 & 30 & 47.2 & 57.2 & 67.3 & 75.6 & 81.2 & 84.0 & 86.0 \\ 120 & & 44.0 & 57.0 & 67.4 & 75.9 & 81.6 & 84.9 & 86.3\end{array}$

Site Index 80

$\begin{array}{rrrrrrrrr}80 & 10 & 50.5 & 61.4 & 72.7 & 82.9 & 91.8 & 98.7 & 101.4 \\ 120 & & 44.9 & 57.2 & 69.3 & 79.9 & 88.8 & 95.1 & 100.1 \\ 80 & 20 & 52.9 & 64.2 & 75.2 & 84.8 & 93.4 & 99.7 & 103.8 \\ 120 & & 48.9 & 62.9 & 75.5 & 86.3 & 95.0 & 101.3 & 106.4 \\ 80 & 30 & 55.9 & 68.2 & 80.8 & 91.5 & 99.0 & 103.0 & 106.0 \\ 120 & & 52.0 & 68.4 & 81.0 & 91.6 & 98.8 & 103.6 & 106.3\end{array}$

\begin{tabular}{|c|c|c|c|c|c|c|c|c|}
\hline \multirow{2}{*}{$\begin{array}{c}\text { Rotation } \\
\text { age }\end{array}$} & \multirow{2}{*}{$\begin{array}{l}\text { Cutting } \\
\text { cycle }\end{array}$} & \multicolumn{7}{|c|}{ Growing stock level } \\
\hline & & 40 & 60 & 80 & 100 & 120 & 140 & 160 \\
\hline \multicolumn{9}{|c|}{ years } \\
\hline $\begin{array}{r}80 \\
120 \\
80 \\
120 \\
80 \\
120\end{array}$ & 20 & $\begin{array}{r}76 \\
88 \\
75 \\
91 \\
86 \\
100\end{array}$ & $\begin{array}{r}95 \\
112 \\
95 \\
116 \\
106 \\
125\end{array}$ & $\begin{array}{l}112 \\
134 \\
115 \\
137 \\
118 \\
140\end{array}$ & $\begin{array}{l}124 \\
149 \\
130 \\
157 \\
122 \\
155\end{array}$ & $\begin{array}{l}135 \\
161 \\
134 \\
164 \\
125 \\
160\end{array}$ & $\begin{array}{r}142 \\
172 \\
138 \\
170 \\
0 \\
160\end{array}$ & $\begin{array}{r}148 \\
173 \\
0 \\
166 \\
0 \\
158\end{array}$ \\
\hline & & \multicolumn{7}{|c|}{ Site Index 60} \\
\hline $\begin{array}{r}80 \\
120 \\
80 \\
120 \\
80 \\
120\end{array}$ & 30 & $\begin{array}{r}98 \\
113 \\
102 \\
121 \\
116 \\
135\end{array}$ & $\begin{array}{l}125 \\
147 \\
130 \\
156 \\
146 \\
170\end{array}$ & $\begin{array}{l}152 \\
179 \\
157 \\
188 \\
168 \\
200\end{array}$ & $\begin{array}{l}174 \\
204 \\
180 \\
215 \\
182 \\
220\end{array}$ & $\begin{array}{l}195 \\
226 \\
194 \\
234 \\
190 \\
230\end{array}$ & $\begin{array}{l}211 \\
242 \\
207 \\
248 \\
195 \\
235\end{array}$ & $\begin{array}{l}223 \\
248 \\
210 \\
251 \\
198 \\
238\end{array}$ \\
\hline & & \multicolumn{7}{|c|}{ Site Index 70} \\
\hline $\begin{array}{r}80 \\
120 \\
80 \\
120 \\
80 \\
120\end{array}$ & $\begin{array}{l}10 \\
20\end{array}$ & $\begin{array}{l}120 \\
138 \\
129 \\
151 \\
146 \\
170\end{array}$ & $\begin{array}{l}155 \\
182 \\
165 \\
196 \\
186 \\
220\end{array}$ & $\begin{array}{l}192 \\
224 \\
199 \\
239 \\
218 \\
260\end{array}$ & $\begin{array}{l}224 \\
259 \\
230 \\
279 \\
242 \\
285\end{array}$ & $\begin{array}{l}255 \\
291 \\
254 \\
304 \\
255 \\
300\end{array}$ & $\begin{array}{l}280 \\
312 \\
276 \\
325 \\
265 \\
310\end{array}$ & $\begin{array}{l}298 \\
323 \\
290 \\
336 \\
268 \\
318\end{array}$ \\
\hline & & \multicolumn{7}{|c|}{ Site Index 80} \\
\hline $\begin{array}{r}80 \\
120 \\
80 \\
120 \\
80 \\
120\end{array}$ & 20 & $\begin{array}{l}142 \\
163 \\
156 \\
181 \\
176 \\
205\end{array}$ & $\begin{array}{l}185 \\
217 \\
200 \\
236 \\
226 \\
270\end{array}$ & $\begin{array}{l}232 \\
269 \\
241 \\
290 \\
268 \\
320\end{array}$ & $\begin{array}{l}274 \\
314 \\
280 \\
340 \\
302 \\
350\end{array}$ & $\begin{array}{l}315 \\
356 \\
314 \\
374 \\
320 \\
370\end{array}$ & $\begin{array}{l}349 \\
382 \\
345 \\
402 \\
335 \\
385\end{array}$ & $\begin{array}{l}373 \\
398 \\
370 \\
421 \\
338 \\
398\end{array}$ \\
\hline
\end{tabular}

'Stand board-foot volume is not computed when average stand d.b.h. is less than 8.0 inches.

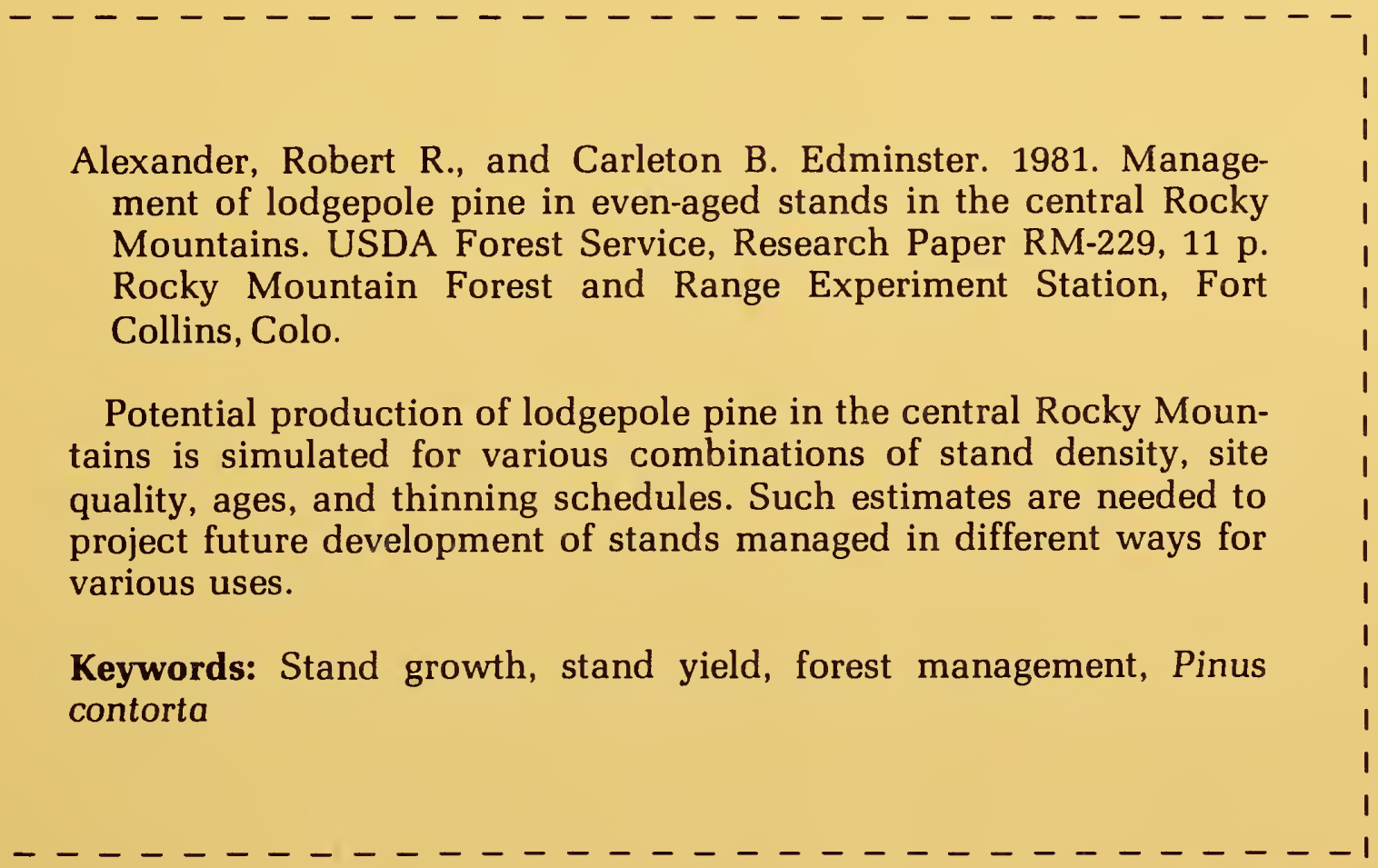




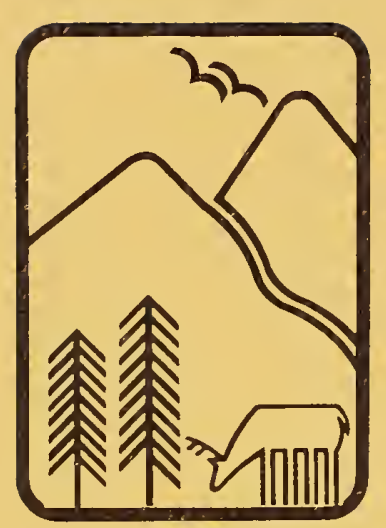

Rocky

Mountains

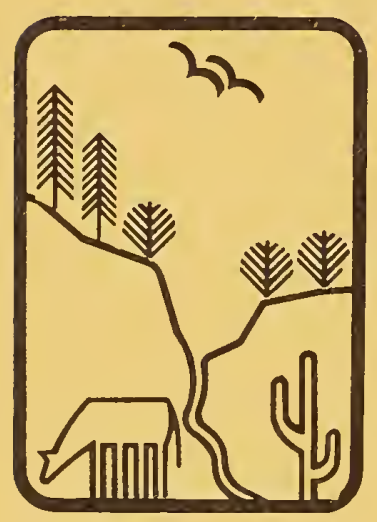

Southwest

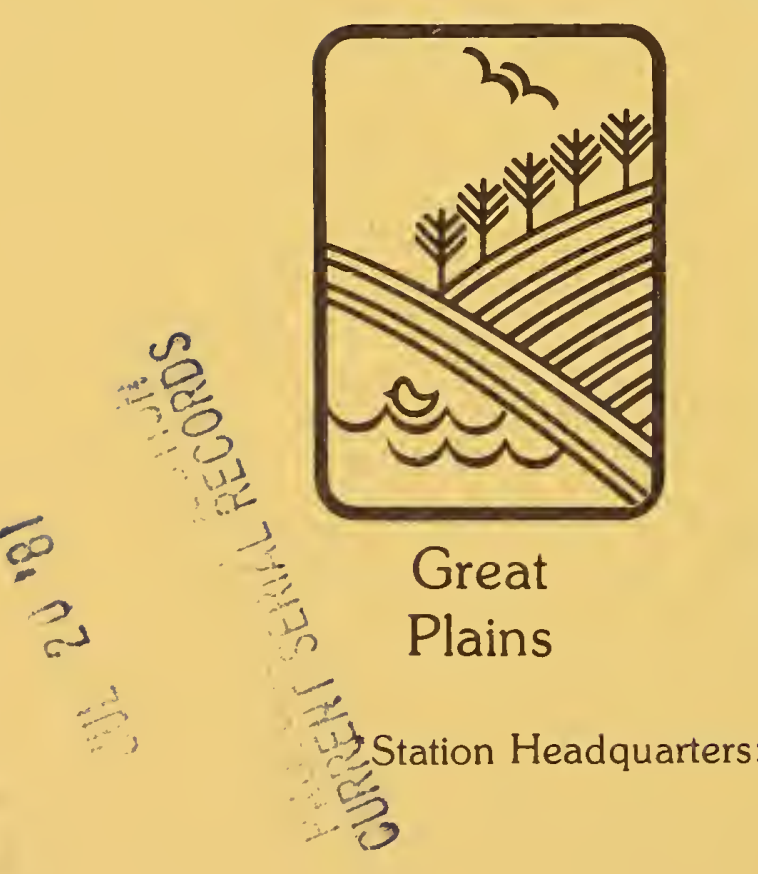

U.S. Department of Agriculture Forest Service

Rocky Mountain Forest and Range Experiment Station

The Rocky Mountain Station is one of eight regional experiment stations, plus the Forest Products Laboratory and the Washington Office Staff, that make up the Forest Service research organization.

\section{RESEARCH FOCUS}

Research programs at the Rocky Mountain Station are coordinated with area universities and with other institutions. Many studies are conducted on a cooperative basis to accelerate solutions to problems involving range, water, wildlife and fish habitat, human and community development, timber, recreation, protection, and multiresource evaluation.

\section{RESEARCH LOCATIONS}

Research Work Units of the Rocky Mountain Station are operated in cooperation with universities in the following cities:

Albuquerque, New Mexico

Bottineau, North Dakota

Flagstaff, Arizona

Fort Collins, Colorado*

Laramie, Wyoming

Lincoln, Nebraska

Lubbock, Texas

Rapid City, South Dakota

Tempe, Arizona 